\title{
STRENGTHENING RELIGIOUS MODERATION TO COUNTER RADICALISM AT IAIN SURAKARTA
}

Moh. Ashif Fuadi, Fuad Hasyim, Muhammad Nur Kholis, Abraham Zakky Zulhazmi, Rustam Ibrahim

UIN Raden Mas Said Surakarta, Jawa Tengah email: moh.ashiffuadi@iain-surakarta.ac.id, hasyim.fuad@ iain-surakarta.ac.id, Muhammad.kholis@iain-surakarta.ac.id, abrahamzakky@gmail.com rustamibrahimalfatih@gmail.com

Abstract: Religious moderation discourse in Indonesia has recently attracted the attention of many parties, especially academics. Moderation means in the middle-center, neither to the right nor the left. In religious issues, religious moderation does not involve radicalism, fundamentalism, and liberalism. It is congruous for religious higher education to be a laboratory of religious moderation. It embeds national ideas, critical thinking constructs, multiculturalism values cultivation, and the peaceful delivery of spiritual messages. This research discusses the implementation of religious moderation at IAIN Surakarta. The internalization of moderation values to students is channeled through Bilik Moderasi Islam dan Adab (BIMA) of the Faculty of Adab and Language. This study employed descriptive qualitative methods with progress reports. It concluded the existence of several channels of moderation at the institutional level. BIMA became one of the pioneers of the religious moderation movement in the faculty. The prevention of radicalism was done in some ways. They establish moderation insight courses, conduct monthly studies on moderation, and create moderation digital creative content. Not only that but also BIMA certificates became the requirement of munaqosah. Besides, the progress report of the moderation index measurement showed the effect of BIMA coaching on the increase in the student moderation index. 
Based on the survey, most students also suggested maintaining the religious moderation education.

الملخص: استحوذ الحديث عن الاعتدال الديني في إندونيسيا مؤخرا على اهتمام العديد

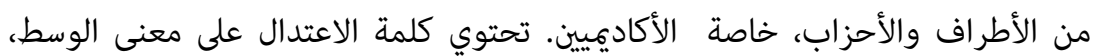

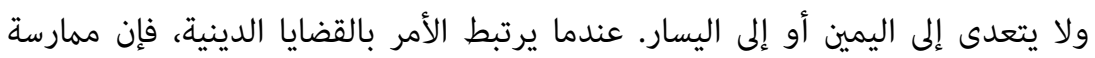

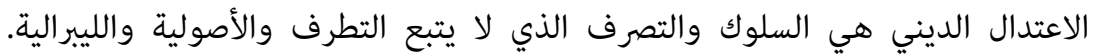

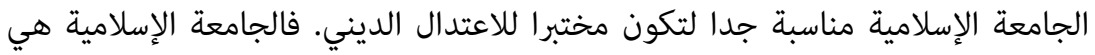

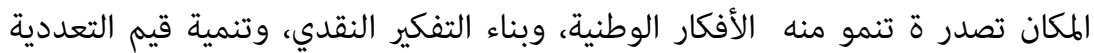

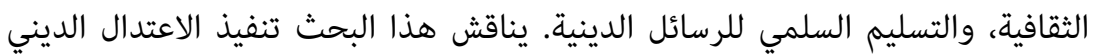

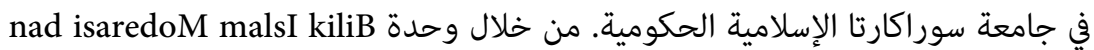

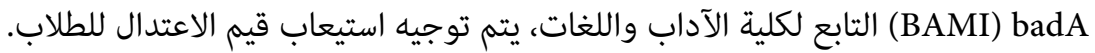

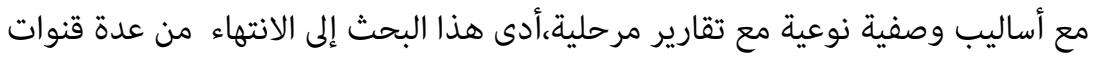

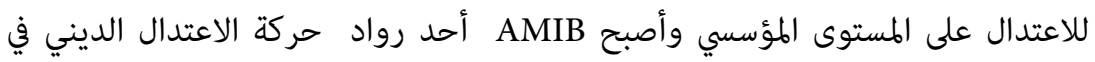

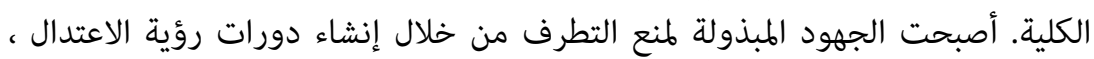

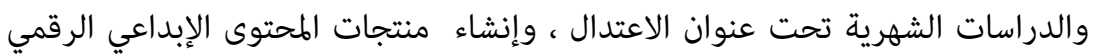

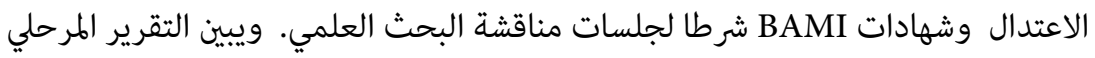

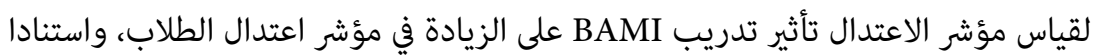

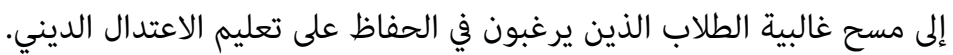

Abstrak: Diskursus moderasi beragama di Indonesia belakangan ini menyita perhatian banyak pihak khususnya kalangan akademisi. Kata moderasi mengandung makna tengah-tengah, tidak ekstrem ke kanan atau ke kiri. Jika dikaitkan dengan persoalan agama, praktik moderasi beragama itu bersikap dan berperilaku yang tidak mengikuti radikalisme, fundamentalisme dan liberalisme. Pendidikan Tinggi Keagamaan sangat tepat menjadi laboratorium moderasi beragama. Perguruan tinggi keagamaan sejatinya menjadi lahan tersemainya gagasan kebangsaan, konstruk pemikiran kritis, penanaman nilai-nilai multikulturalisme dan penyampaian pesan agama yang damai. Penelitian ini membahas tentang implementasi moderasi beragama di IAIN Surakarta. Melalui unit Bilik Moderasi Islam dan Adab (BIMA) Fakultas Adab dan Bahasa, maka internalisasi nilai-nilai moderasi kepada mahasiswa disalurkan. Dengan 
metode kualitatif deskriptif dengan progress report, penelitian ini menghasilkan kesimpulan adanya beberapa saluran moderasi di tingkat institusi dan BIMA menjadi salah satu pelopor gerakan moderasi beragama di fakultas. Upaya pencegahan radikalisme dilakukannya melalui penetapan mata kuliah wawasan moderasi, kajian bulanan bertemakan moderasi, pembuatan produk konten kreatif digital moderasi dan sertifikat BIMA menjadi syarat untuk sidang munaqosah. Adapun progress report pengukuran indeks moderasi menunjukkan aadanya pengaruh pembinaan BIMA terhadap kenaikan indeks moderasi mahasiswa dan berdasar survei mayoritas mahasiswa menginginkan edukasi moderasi beragama terus dipertahankan.

Keywords: BIMA, Counter-radicalism, religious moderation.

\section{INTRODUCTION}

Indonesia is currently facing the problem of intolerance and radicalism in various sectors. Based on survey data in 2018-2019 in several segments, universities have anti-religious students. They tend to behave intolerantly in the same but different schools. ${ }^{1}$ The increasing complexity of challenges in education is characterized by the proliferation of groups of students who exclusively themselves who infiltrate the College of Diversity. As a result, this wave of ferocious, fierce-faced, exclusive student groups builds a solid community with rigid, ideological fragments and sows suspicion of different groups. Islamic Religious College is a melting pot where various views, approaches, and reasoning come with academic and scientific responsibilities. $^{2}$ Therefore, strengthening religious moderation is presented as a comprehensive solution that can answer the problem. Every individual adherent of any religion and belief of ethnicity, culture, religion, and political choices must be willing to listen to each other and learn to manage and overcome differences.

1 PPIM UIN Jakarta, "Ringkasan Eksekutif Hasil Penelitian Potret Moderasi Beragama di Kalangan Mahasiswa Muslim Kasus Tiga Kampus Islam (Jakarta, Bandung, Yogyakarta)," 2021, 4.

2 Tim Penyusun Kementerian Agama, Moderasi Beragama (Jakarta: Badan Litbang dan Diklat Kementerian Agama RI, 2019), iv. 
Streng thening religious moderation is also a priority program that is part of the mental revolution and cultural development in the National Medium-Term Development Plan (RPJMN) 2020-2024. ${ }^{3}$ This policy strengthens religious moderation as the foundation of religious attitudes and practices. It is because of the weak understanding and experience of religious values, inclusive, and intolerant. It is also carried out comprehensively, covering five priority activities ranging from education, harmony, culture, religious services to the economy.

Religious moderation is expected to be relegated into the strategic plans of every ministry and institution. Thus, the problem of intolerance and radicalism can be overcome. Moreover, there is a moral degradation of the next generation of the nation in the current era. There are many cases of spreading hoaxes. In addition, the results showed an alarming level with the emergence of radical and intolerant religious understanding both inside and outside religion. The moderation space that became culture and culture in the State Islamic Religious College (PTKIN) became threatened. The condition that encourages strengthening the understanding of Muslim moderation is the religion that rahmatan lil älaminn. According to Ruchman Basori, the sub-division head of Student Affairs Directorate of Islamic Religious Higher Education, students should be the locomotive of religious moderation among students of Islamic Religious Colleges (PTKI) to overcome the growth of intolerance and radicalism. Research shows that $39 \%$ of students exposed to radicalism became a critical alarm for universities' academic community, including the administrators of organizations.

3 Demsy Jura, "Religious Moderation: An Approach Of Religious Life In Indonesia," Jurnal Inovasi Penelitian, Volume 1, No. 10, (2021), 8. meaning that every religious follower is required to practice his religious beliefs correctly while respecting the existence of other religious followers. Religious moderation provides new choices and is in the middle axis in living a religious life, namely between religion's radicalism and religion's liberalism",,"author":[\{“dropping-particle":”,,’family":”Jura”,"given" :"Demsy","non-dropping-particle":",,"parse-names":false,"suffix":"”, ],"container-

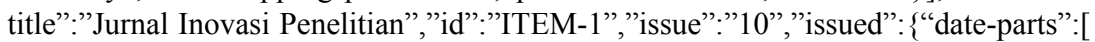
[“2021"]]\},"title":"RELIGIOUS MODERATION: AN APPROACH OF RELIGIOUS LIFE IN INDONESIA","type":"article-journal","volume":"1"”,,"uris":[“http://www. mendeley.com/documents/?uuid=40102077-853a-4412-aaec-c3389704e206"] \}],"m endeley": \{“formattedCitation":"Demsy Jura, "RELIGIOUS MODERATION: AN APPROACH OF RELIGIOUS LIFE IN INDONESIA," <i>Jurnal Inovasi Penelitian</ i> 1 , no. $10(2021$ 
Religious moderation campaigns and moral development became essential points to answer the problem of intolerance and radicalism among the younger generation, especially students of the Faculty of Adab and Language (FAB) IAIN Surakarta. It is because Tarbiyah movements such as P3KMI at the Faculty of Tarbiyah Science IAIN Surakarta at that time became a medium of ideologically transnational seeding movements. ${ }^{4}$

Therefore, after experiencing the faculty division from FITK to the Faculty of Adab and Language (FAB) in 2018, the dean of the new faculty used policy instruments. By establishing support units of Bilik Moderasi Islam dan Adab (BIMA), it restrains underground movements. Some are worried about the sowing ground of intolerant activities that lead to radicalism on campus. This research discusses how to strengthen religious moderation at IAIN Surakarta, especially those carried out by BIMA. It also describes the implementation of the religious moderation value to restrain transnational ideological movements that have previously entered through the channels of student activities.

The $\mathrm{m}$ ethod used in this study was a literature review. According to Danandjaja, reference sources in library research can be done by analyzing articles, books, and writing sources relevant to the theme. ${ }^{5}$ This research was descriptive research with a qualitative approach. According to Sugiyono, the qualitative descriptive method is a research method based on the philosophy of post positivism. It is use d to examine the condition of natural objects (as opposed to experiments). He also said that the researcher is a crucial instrument of data collection techniques carried out by triangulation (combined). The da ta are analyzed inductively/qualitatively. The qualitative research results emphasize the meaning of generalization. ${ }^{6}$ To find out the application of embedding moderation values, it conducted field

4 Toto Suharto and Ja'far Assegaf, "Membendung Arus Paham Keagamaan Radikal Di Kalangan Mahasiswa PTKIN," Al-Tahrir: Jurnal Pemikiran Islam, Volume 14, No. 1, (2014): 8, https://doi.org/10.21154/al-tahrir.v14i1.72.

5 James Danandjaja, Folklor Indonesia: Ilmu Gosip, Dongeng, dan lain-lain, (Jakarta: PT. Pustaka Utama Grafiti, 1997), 87.

6 Sugiyono, Metode Penelitian Bisnis: Pendekatan Kuantitatif, Kualitatif, Kombinasi, $R \& D$, ed. Sofia Yustiyani Suryandari, 3rd ed. (Bandung: CV Alfabeta, 2017), 28. 
observations through a google form that contains questions related to moderation to investigate the progress reports.

\section{INTERPRETING RELIGIOUS MODERATION}

The term religious moderation in Indonesia is often identified with the concept of wasathiyah. According to M. Khalid Syaerazi, the essence of Islamic teachings is wasathiyah, both in worship, social behavior, economics, and as a community. Esktrem attitude is not desired in Islam. The Prophet said that the best thing is in the midst. In the Context of Indonesia, Aswaja is a form of wasathiyah diniyah. NKRI based on Pancasila is wasathiyah siyasiyah. The idea of cooperatives is wasathiyah iqtishadiyah. The narrator of the ukhuwah trilogy is wasathiyah ta' amuliyah. ${ }^{7}$

M. Qur aish Shihab called moderation or wasathiyah, not an attitu de that is not clear or indecisive as neutral and passive. One indicator of wasathiyah is humility and manners, but that does not mean y ou should not face a problem firmly. The characteristic of wasathiyah is to be fair, which is to put everything in its place. Shihab emphasized that the issue of wasathiyah is not just a question of people per person. It is a question of people and nations. Especially now that various ideologies have entered Indonesia. ${ }^{8}$

The position in the middle is because if in the study of kalam science, there are called tatharruf tasyaddud (extreme right) and tatharruf tasahhuli (extreme left). ${ }^{9}$ The first religious puritanism characterizes the extreme right. Puritanism is derived from the pure root word meaning pure. The puritanical group wants to return the teachings of religion to the pure instructions of the jargon "let's go back to the Qur'an and hadiths." ${ }^{10}$ Religious puritanism implications

7 M. Kholid Syeirazi, Wasathiyah Islam; Anatomi, Narasi dan Kontestasi Gerakan Islam (Bekasi: alif.id, 2020), ix.

${ }^{8}$ M. Quraish Shihab, Wasathiyah; Wawasan Islam tentang Moderasi Beragama. (Tangerang: Lentera Hati, 2019), x.

9 The Ministry of Religious Affairs from the beginning clearly took this position of Islamic moderation for the religiousness of Indonesian Islam. This position was also strengthened by the Indonesian Ulema Council which affirmed that MUI's vision was to develop the teachings of Wasathiyah Islam., lihat Toto Suharto, "Remoderasi Pendidikan Islam Di Indonesia: Tantangan Ideologis," IAIN Surakarta, February (2020): 9.

${ }^{10}$ Rendy Adiwilaga, "Puritanisme Dan Fundamentalisme Dalam Islam Transnasional Serta Implikasi Terhadap Pancasila Sebagai Ideologi Bangsa,” Journal 
are th at all religious activities are united with tradition. It also collaborates with culture, such as prophetic mauled, tahlilan, grave pilgrimage, commemoration haul, and others considered heretics.

The se cond extreme right religion is fundamentalism and radicalism. These are two things that are connected. Fundamentalism is taken from the root of the word fundament. It means basic. Moreover, radicalism is derived from the Latin radix, meaning root. ${ }^{11}$ They are the same. In addition, takfiri is the act of disbelieving. It is one level above puritanism. The system of democracy, nationalism, Pancasila ideology is considered infidel (thaghut). ${ }^{12}$ At the same time, the third level is the most extreme fundamentalist, and the radical group is the irhabi (terrorism). The third habitat of the extreme third right is used to take verses of the Qur'an. It is wa man lam yahkum bimā anzalallahu faulāika humul käfirun. It means those who do not punish the law of Allah then they are infidels so that their blood is halal and may be killed. ${ }^{13}$ As for the extreme left termed tasahhuli or liberalism, taken from the root of the word to liberate means liberating. ${ }^{14}$ The meaning of Islam is submission or surrender, while tasahhul is too easy to religion. Although religion is easy, it should not be assuredly displayed according to the taste of reason.

The position of the religious moderation movement is in the middle by sticking to the truth. Still, the first attitude is a tasāmuh attitu de full of tolerance, the second tawassuth and i'tidal hold to justice, the third tawäzun balanced. ${ }^{15}$ In daily life, the moderate person spreads positive vibes. They greet and smile at others as the teachings

of Governance, Volume 2, No. 1, (2017): 132.

${ }^{11}$ Muhammad Harfin Zuhdi, "Radikalisme Agama dan Upaya Deradikalisasi Pemahaman Keagamaan," Akademika, Volume 22, No. 1, (2017): 202.

${ }^{12}$ M. Hafidh Widodo, "Ideologi Takfiri Muhammad Al-Maqdisi : Memahami Hubungan Beragama dan Bernegara Perspektif Maqāshid Asy-Syarī'Ah," Living Islam, Volume 1, No. 2 (2018): 392.it is stated that kaafir is a person who does not believe that Allah Swt. as God Almighty, people who worship idols, and Ahl Kitab (Jewish and Christian

${ }^{13}$ Ahmad Jazuli, "Strategi Pencegahan Radikalisme dalam Rangka Pemberantasan Tindak Pidana Terorisme," Jurnal Ilmiah Kebijakan Hukum, Volume 2, No. 10, (2016): 201.

${ }^{14}$ Muhammad Nurkhoiron, "Liberalisasi Sebagai Moderasi Islam dalam Masyarakat Paska Sekuler," MIMIKRI, Volume 6, No. 1, (2020): 3.

${ }^{15}$ Mohamad Fahri and Ahmad Zainuri, "Moderasi Beragama di Indonesia," Intizar, Volume 25, No. 2, (2019): 97. 
of the Prophet. It is tabassumuka fi wajhi akhika shodaqoh, which means your smile to your brother is almsgiving.

The moderate feature of nature responds to differences. Suppose anyone comes to discuss coming to argue. In that case, he sticks to the Qur'an. Ud'ü ilā sabïli rabbika bi al-hikmah wa mauidzat al-hasanah, wajāilhum billati hiya ahsan. It means invite humans to the way of your Lord in a dignified way and good advice (mauidzatil hasanah). Wajādilhum billati hiya ahsan means if you have to argue, then argue in a dignified way by putting forward $a d a b$ and morale.

Its im plementation in the context of Indonesian, Azra states that diversity in Indonesia is different from other places because, in Indonesia, it highlights inclusive things. ${ }^{16}$ In this case, the most visible is the number of Indonesian Muslims, $88.2 \%$ of the 260 million population. It causes many observers in Europe and America to be still astonished by Indonesia. It is known that the majority of its citizens are Muslim. They question why Indonesia does not become an Islamic country and is not a state based on Islam. While in Europe itself, there are many countries based on Christianity, especially such as Calvinists, Lutherans, and Anglicans. Therefore, it is very well seen historically in the formation of the Indonesian state since August 17, 1945. Today, moderation still has become an actual manifestation of diversity.

Furthermore, in accepting Islam as the largest ummah (Muslim community) in legitimizing Pancasila, it is based on the four basic principles of the Indonesian nation-state. They are the 1945 Constitution, NKRI, Pancasila, and Bhineka Tunggal Ika. That's what's been shown throughout the history of democracy in Indonesia. It is also seen in various sectors of life where non-Muslims can be the leaders or public officials. For example, become the ministers, governors, regents, and mayors. The law also further strengthened that there are no obstacles such as resident and representative president; it must be Muslim. It also demonstrates the vital moderation of Muslims once again as the most prominent citizen in Indonesia.

${ }^{16}$ Azyumardi Azra, "Distinguishing Indonesian Islam: Some Lessons to Learn," ed. Jajat Burhanudin and Kees van Dijk (Amsterdam: Amsterdam University Press, 2013), 63 . 


\section{URGENCY OF IMPLEMENTING RELIGIOUS MODERATION IN PTKI}

Since 2019, the Ministry of Religious Affairs has been the initiator of the concept of religious moderation. The idea has been included in the National MediumTerm Development Plan (RPJMN) 2020-2024. ${ }^{17}$ In addition, a circular was also issued by the director-general of Islamic Education related to the establishment of a Religious Moderation House in PTKI. Religious moderation is conceptually a religious attitude balanced between one's own religious experience and respect for the religious practices of others of different faiths. ${ }^{18}$ The Ministry of Religious Affairs has established indicators of religious moderation. They are national commitment, tolerance, non-violence, and accommodative attitudes towards local culture. ${ }^{19}$

Islamic Religious College (PTKI) is a center for Islamic studies. That is because the majority of Muslims are essential to developing and ma instream religious moderation. UIN Jakarta Islamic and Commun ity Assessment Center (PPIM) through convey Indonesia progra $m$ conducted research on three PTKIN in Indonesia, namely UIN Syarif Hidayatullah Jakarta, UIN Sunan Gunung Djati Bandung, and UIN Sunan Kalijaga Yogyakarta. Research focuses on external empath $y$, internal empathy, social dominance orientation, antiviolen ce attitudes, and civic attitudes and behaviors derived from indicators of religious moderation, with the number of respondents as many as 1066 students and 125 lecturers and university officials. ${ }^{20}$ The survey was conducted online from September to December 2020. Selain, PPIM also conducted 12 focus group discussion sessions in 2nd-se mester students, students in student organizations, lecturers, rectorates, deans, and institutions. The purpose of this research is as

${ }^{17}$ Tim Penyusun Kementerian Agama, Moderasi Beragama (Jakarta: Balitbang dan Diklat Kementerian Agama, 2019), 128.

${ }^{18}$ Kementerian Agama RI, Rencana Strategis Kementerian Agama Tahun 2020-2024, 2020, 81, https://bali.kemenag.go.id/uploads/media/2020/07/RENSTRA_ KEMENAG_2020-2024.pdf.

19 Tim Penyusun Kementerian Agama, Moderasi Beragama, 2019, 44.

${ }^{20}$ PPIM UIN Jakarta, "Ringkasan Eksekutif Hasil Penelitian Potret Moderasi Beragama di Kalangan Mahasiswa Muslim Kasus Tiga Kampus Islam (Jakarta, Bandung, Yogyakarta),” 2021, 3.. 
an initial study in making a design to increase the capacity of PTKI in promoting religious moderation. ${ }^{21}$

The study concludes nine points with two main strengths. First, religious moderation has been inserted in education and teaching and the many themes of religious moderation in student activities. However, things still need to be strengthened again, such as the absence of standard guidelines for implementing religious moderation. Religious modera tion house has not entered the organizational structure of work, so it is not free to regulate the budget. There is no need for monitoring and structured evaluation. Based on these findings, it can be said that state religious universities have not been able to carry out their role to the maximum as agents of religious moderation. To follow up the results of PPIM has also held capacity building on 38 houses of religious moderation in Indonesia. The technical assistance discussed the recommended training modules with three PTKIN that were the target of the research. From the results of this study, efforts to mainstream religious moderation, namely to regulate the structure of the House of Religious Moderation, create a religious moderation measur ement index, guidance, or Standard Operating Procedure (SOP) for The House of Moderation and a structured monitoring and evaluation system at PTKIN. ${ }^{22}$

Furthe rmore, Lukman Hakim Saifuddin hopes that the entire ranks of the Ministry of Religious Affairs state civil apparatus will be the leading parties. They understand, believe, and internalize the spirit of religious moderation. They do it in personal and community life, nation, and state, through various programs according to their respective work units. ${ }^{23}$

${ }^{21}$ Pusat Pengkajian Islam \& Masyarakat UIN Jakarta, "Penelitian Sikap Dan Perilaku Terhadap Keberagaman, Berbangsa Dan Bernegara Pada Civitas Akademika PTKIN," SURVEI PPIM UIN JAKARTA, 2021, https://ppim.uinjkt.ac.id/publikasi/ survei-ppim/.

${ }^{22}$ PPIM UIN Jakarta, "Ringkasan Eksekutif Hasil Penelitian Potret Moderasi Beragama Di Kalangan Mahasiswa Muslim Kasus Tiga Kampus Islam (Jakarta, Bandung, Yogyakarta)," 9.

${ }^{23}$ Tim Penyusun Kementerian Agama, Moderasi Beragama, 2019, iv. 


\section{ACTUALIZATION OF RELIGIOUS MODERATION AT IAIN SURAKARTA}

Religious moderation is not merely a discourse. It also actualized at IAIN Surakarta. According to the interview with the Inspectorate General of the Ministry of Home Affairs, Mudhofir, the Rector of IAIN Surakarta, the campus had already created a Religious Moderation House board. They established and implemented their programs. Then the second is the existance of Pusat Studi Pendidikan dan Kebijakan (PSPK), which aims to refresh the values of Pancasila in life on campus. Although not directly related, Pusat Komunikasi dan Pemberdayaan Pesantren Nusantara (PKPPN) aims to empower and build pesantren campaigning for Islamic manners at every opportunity. In addition, LP2M manages the development of research on religious moderation. ${ }^{24}$

Historically Surakarta as a market place node point meets the seeds of radicalism that give rise to clashes of any ideology. For example, in about 2006, STAIN Surakarta students of the Faculty of Sharia died with Dr. Azhari in Batu Malang. But in the 3rd semester no longer continued the lecture. It shows that the IAIN Surakarta campus is surrounded by associations that need to be watched in preventive operations. Besides being surrounded by various organizations with characters such as MTA (Majlis Tafsir al-Qur'an), Jam'iyah Anshorut Tawhid led by Abu Bakar Ba'asyir, and so on.

In other implementations, in utilizing social media that is already global, good literacy needs to be developed using the best digital century ever achieved by humans. IAIN Surakarta has included moderation in various activities to combat the hoax regarding spreading issues or hoaxes. For example, the Introduction to Academic and Student Culture (PBAK), graduation, and other activities.

The st rategic instrument to moderate students is through the activi ties of students. For example, KKN IAIN Surakarta in 2020 through KKN Online Social Work From Home (kerso darma) carries the theme of religious moderation. According to Abraham Zakky,

${ }^{24}$ Rumah Moderasi dibentuk berdasarkan keputusan rektor Institut Agama Islam Negeri Surakarta Nomor 172 Tahun 2021 tentang perubahan atas keputusan rektor Institut Agama Islam Negeri Surakarta Nomor 239 tahun 2020 tentang Pengelola "Rumah Moderasi Beragama" Institut Agama Islam Negeri Surakarta tahun 2021-2023. Untuk PSPK mengacu pada keputusan rektor Institut Agama Islam Negeri Surakarta Nomor 227 Tahun 2020. 
religious moderation can be interpreted as an option to look at behavior and at titude. It takes in the middle, not extreme and excessive in religious moderation. It is well-known as wasathiyah. It is in line with the message of the Qur'an. It is stated that man is asked to be a people who are in the midst of a person. Furthermore, KKN in 2021 carries the theme "Strengthening Community Resilience during the Covid-19 Pandemic Based on Local Wisdom and Religious Moderation". ${ }^{25}$

Religious moderation needs to be realized as a behavior for everyday life because all have a social responsibility to maintain national harmony. So religious moderation is essential and relevant, mainly associated with the transformative KKN kerso darma in 2020, which carries the theme of religious moderation. KKN kerso darma on religious moderation inspires students to write reports in the form of journal articles or essays in the perspective of religious moderation.

Furthermore, reports in essays or journal articles related to religious moderation can also show the relationship between religious moderation and local wisdom. There is a practice of religious moderation that departs from the concept of something universal and something local in society. For example, the universal must close the aurat (nakedness). Closing the aurat is universal. Every Muslim must cover the aurat, but the local expression will appear different than when covering the aurat using a sarong using batik. It is a local expression. Another example is that it can be seen in the atmosphere of Eid al-Fitr. Muslims all over the world celebrate Eid in the first Shawal without any particular tradition. However, Eid al-Fitr in Indonesia has its tradition, such as ketupat, sungkeman, sharing Fitrah. They ate the expression of local expression where culture and religion are united and not negated. The reports of the transformative KKN 2020 are in the form of essays or journal articles. It encourages a religious moderation theme. It includes tasamuh (tolerance), tawazun (balanced), then i'tidal (fair), and tawassuth (neutral). These four things became spirit or spirit in implementing religious moderation in Indonesia and KKN IAIN Surakarta students 2020. Furthermore, each student can follow up the practice of religious moderation in the community. They can

${ }^{25}$ LP2M IAIN Surakarta, "Pengumuman Pembagian Kelompok Dan Dosen Pembimbing Lapangan (DPL) KKN Kerso Darma 2021,” LP2M, 2021, https://p2m. iain-surakarta.ac.id/2021/06/13/pengumuman-pembagian-kelompok-dan-dosenpembimbing-lapang-dpl-kkn-kersodarma-2021/. 
be the ambassador for religious moderation because they have learned about it on campus. Thus, they become moderate and tolerant Muslims to reach the spirit of religious moderation in the community.

\section{IMPLEMENTATION OF BIMA COUNTER RADICALISM}

Since 2006 Program Pendampingan Pengembangan Kepribadian Muslim Integral (P3KMI) transformed the material aspect. It only focuses on learning to read and write the Qur'an (BTA). It is because it adjusts the needs of students partly from schools with formal institutions, not religious (pesantren). Therefore, they have not mastered reading the Qur'an. The P3KMI program is intended for new students for one year. It is managed directly by students both as managers and as mentors. In addition, the obligation for every graduate of IAIN Surakarta must be able to read and write the Qur'an. ${ }^{26}$ In 2018 the Faculty of Tarbiyah and Teacher Training (FITK) IAIN Surakarta became two faculties. They were the Faculty of Tarbiyah Science (FIT), and the Faculty of Adab and Language (FAB) Program originating from FITK continued at the Faculty of Adab and Language.

In developing the flow of the Tarbiyah movement in PTKIN, in this case, is IAIN Surakarta through an integral Muslim development assistance program (P3KMI) Faculty of Tarbiyah and Teacher Training (FITK). Rohis program channels the movement through liqa'. It slips exclusive Islamic understanding that is puritanical through guidebooks and indoctrination processes. It is by learning to read the Qur' an (BTQ) and worship practices. ${ }^{27}$ Therefore, a coaching program is needed to establish inclusive aspects of understanding the Faculty of Adab and Language students through the Islamic moderation chamber and adab (BIMA). In 2019 P3KMI changed its name to BIMA, which contains material about religious moderation and the development of adab and

${ }^{26}$ Tim P3KMI Fakultas Tarbiyah dan Bahasa IAIN Surakarta, Muslim Integral: Buku Program Pendampingan Pengembangan Kepribadian Muslim Integral (P3KMI), Cet.I (Yogyakarta: Cipta Media Aksara, 2012), 2-3.

${ }^{27}$ Toto Suharto and Ja'far Assagaf, "Membendung Arus Paham Keagamaan Radikal di Kalangan Mahasiswa PTKIN," Al-Tahrir: Jurnal Pemikiran Islam, Volume 14, No. 1, (2014): 1, https://doi.org/10.21154/al-tahrir.v14i1.80. 
morals. At the same time, the reading material was written by the Qur'an as an assignment from the Pondok BTQ FAB Unit program. ${ }^{28}$

Accord ing to Toto, as The Dean of FAB, he first initiated a religious moderation program before the public established the House of Moderation. It is due to the IAIN Surakarta factor is different, especially in terms of student background. The number of alumni from high school that may be religious understanding is still lacking except those from high schools based on pesantren. ${ }^{29}$

The FAB environment realized that one of them was managed by the BIMA unit. There are only two colleges that state the religious moderation insight courses officially. They are IAIN Surakarta and UIN Walisongo. In the context of IAIN Surakarta as a marketplace area of diversity streams, especially for the 2020 generation to borrow the term Darwin with the missing link has not met with his older brother, who is 2019 but already wants to have a younger brother in 2021 . That group has not been detected about the way its religious views and attitudes. Thus, including the House of Religious Moderation for the context of IAIN is to detect the missing link because the campus has not been able to monitor student activities during this online pandemic. One of the BIMA outputs is a certificate as a condition to follow munaqosah. ${ }^{30}$

Accord ing to Fuad Hashim, chairman of the IAIN Surakarta Religi ous Moderation House, one of the strategic projects of the Ministry of Religious Affairs is specifically to implement religious operat ions, especially for students or the environment outside of students in external dance from campus because the campus has not become the primary agent to mainstream religious moderation. As a student, you should be an agent of religious moderation, especially to create peace. Religious moderation creates a conducive community atmosphere, of course, spiritual with a straight view and not simply consumed by issues. Moderates here are done in the context of putting things in their place and not overdoing it in fanaticism. House of

${ }^{28}$ Surat Keputusan Rektor Institut Agama Islam Negeri Surakarta Nomor 392 Tahun 2019.

${ }^{29}$ Interview with Toto Suhato (Dekan Fakultas Adab dan Bahasa), 2 September 2021.

${ }^{30}$ Interview with Toto Suhato (Dekan Fakultas Adab dan Bahasa IAIN Surakarta), 2 September 2021. 
Religious Moderation in IAIN Surakarta gets the mandate to educate IAIN Surakarta Religious Moderation House. ${ }^{31}$

Accord ing to Toto Suharto, school-age teenagers are very vulner able to the radical doctrines and understandings they receiv e. Extremist-radical groups have exploited this opportunity to ind octrinate them into the ideology of martyrdom, which is that dying in the name of Islam will ensure they go to heaven. Theological elements are the main factors behind their willingness to join radical groups in educational institutions. In addition, to a combination of other social, political, and economic factors. Therefore, stemming is the main factor of the radicalization of the millennial generation. An antidote is needed to radicalism. It is how educational institutions teach moderate Islamic doctrine to them ideologically. ${ }^{32}$

Islamic education is one of the keys to stopping or slowing the spread of radical extremist ideology. By the character of religious modera tion, Islamic education as a form of cultural approach in counte r-radicalism contains four things: national commitment, tolerance, nonviolence, and accommodation to local culture..$^{33}$

Furthe rmore, BIMA became a supporting unit of the Faculty of Ada $b$ and Language in developing the learning of religious moderation and morals. The character of the Faculty of Adab and Langua ge upholds Islamic values. Adab became a critical point to answer the problem of intolerance and radicalism among the younger generation, especially FAB IAIN Surakarta students. Therefore, the lectur ers and the students of FAB initiated a moral development program with a religious moderation curriculum to prevent radicalism for FAB students in the first and second semesters. Units and students' teams manage BIMA as this program is established in the Faculty of Adab and Bahasa. At the same time, the implementation and target are

${ }^{31}$ Interview with Fuad Hasyim (Ketua Rumah Moderasi Beragama IAIN Surakarta), 18 August 2021.

${ }^{32}$ Toto Suharto, Moderasi Bergama Berbasis Kurikulum Islam Rahmatan Lil'Alamin (Jakarta: Puslitbang Pendidikan Agama dan Keagamaan Badan Litbang dan Diklat Kemenag, 2020), 8. See Dina Afrianty, "Islamic Education and Youth Extremism in Indonesia," Journal of Policing, Intelligence and Counter Terrorism, Volume 7, No. 2 (2012): 134-46.

${ }^{33}$ Tim Penyusun Kementerian Agama, Moderasi Beragama, 2019. 
students themselves. BIMA has a goal-setting so that FAB students have Islamic morals and adab in religious moderation. ${ }^{34}$

Bima program is intended mainly for early semester students within one year. BIMA administrators and their members manage it. Optimizing the role of BIMA program students is one of the Faculty of Adab and Language IAIN Surakarta Language advantages compared to other faculties. Therefore, the material delivered related to the understanding of religious moderation is combined with various basic disciplines in morals.

One of the leading programs of BIMA is the creation of creative content in the form of videos intended for new students as a final assignment or output. ${ }^{35}$ This product will be selected, and then the selected will be uploaded on BIMA's Youtube social media to attract more viewers from various circles. Youtube is an effective medium to spread the message of religious moderation. Even the databox web page, the large audience on this media mentions that $94 \%$ of internet users in Indonesia aged 16-64 years access Youtube. ${ }^{36}$ Seeing the fans of Youtube videos that are so large, even the majority users, then the potential to spread moderation messages becomes more open. This moderation video creation training is intended for new students who will each be accompanied. The results or output in the form of moderation videos will be selected and uploaded on Youtube.

Another BIMA program creates comics or moderation posters intended for new students as a final assignment or output. The creation of this moderation comic is nothing but aimed at implementing religious moderation in comics. A study mentioned that Indonesia became the second-ranked country for the number of comic readers after Finland. ${ }^{37}$ So this media is quite popular among millennials, hoping that comics

${ }^{34}$ Tim BIMA, "BIMA (Bilik Moderasi Islam dan Adab)," Fakultas Adab dan Bahasa IAIN Surakarta, 2020, https:/fab.iain-surakarta.ac.id/unit-penunjang/unitp3kmi/.

${ }^{35}$ Arindya Iryana Putri, "Seminar BIMA (Bilik Islam Moderasi dan Adab) Makna \& Penguatan Nilai-Nilai Moderasi Islam di Era Digital," Fakultas Adab dan Bahasa IAIN Surakarta, 2020,https://fab.iain-surakarta.ac.id/seminar-bima-bilik-islammoderasi-dan-adab-makna-penguatan-nilai-nilai-moderasi-islam-di-era-digital/.

${ }^{36}$ Andrea Lidwina, "94\% Orang Indonesia Akses YouTube Dalam Satu Bulan Terakhir," Databoks, 2021.

${ }^{37}$ Faizal Irfandi Aldy Aldya Putra, "Implementasi Quick Response (QR) Code Pada Aplikasi Pratinjau Konten Komik Cetak," Jurnal Siliwangi, Volume 4, No. 2, (2018): 104-11. 
become one of the media that can understand religious moderation to the community, especially millennial children.

This comic creation program will be for FAB new students who understand religious moderation and digital comic creation training. Digital comic products will be published through certain websites to be accessible to millennial children, such as webtoons and others. Students who participate in this program approximately 900 will be divided into three groups: a poster-making training group or religious modera tion comics. Thirty mentors will accompany religious modera tion comics, with each group consisting of 10 people or students. Wildan stated that religious moderation can be more voiced through digital media according to the digital society now dominated by millennials. ${ }^{38}$

Another BIMA program that is no less interesting is the training of mak ing religious moderation articles. It is considered necessary becaus e many things in today's digital era where the writing consumed by millennials is much discriminatory, spreading hoaxes, slander, criticizing, and hatred. The function of spiritual development for st udents in Islamic Religious Colleges is not only in terms of cognitive but rather the cultivation of spirituality that boils down to the formation of noble morals. ${ }^{39}$

One of the essential programs in introducing BIMA is a seminar for new students. This activity is required for new students of the Facult y of Adab and Language. This bima introduction seminar will synergize BIMA programs to students in the Faculty of Adab and Language. The seminar explained the importance of BIMA as a unit in the Faculty of Adab and Language. It will campaign for the Ministry of Religious Affairs program, namely religious moderation and BIMA certificate, which will require munaqosah examination..$^{40}$ Thus, an essential and strategic instrument to remoderate Indonesian

${ }^{38}$ Wildani Hefni, "Moderasi Beragama Dalam Ruang Digital: Studi Pengarusutamaan Moderasi Beragama Di Perguruan Tinggi Keagamaan Islam Negeri," Jurnal Bimas Islam, Volume 13, No. 1, (2020): 17, https://doi.org/10.37302/jbi. v13i1.182.

${ }^{39}$ Fathudin AW Syukri and Sudiyatno, "Peningkatan Perilaku Religius Mahasiswa Melalui Integrasi Pembelajaran Pendidikan Agama Islam (PAI) Dan Pembinaan di Unit Kegiatan Keagamaan Mahasiswa," Seminar Hasil Penelitian Lemlit UNY, 2008.

${ }^{40}$ Putri, "SEMINAR BIMA (Bilik Islam Moderasi dan Adab) Makna \& Penguatan Nilai-Nilai Moderasi Islam di Era Digital.” 
Islam is through educational channels. Bima unit plays its role in the college as a guardian of moderation, especially in the Faculty of Adab and Language. Sutrisno's statement explains that educational institutions, colleges, are appropriate in sowing religious moderation. ${ }^{41}$

The Faculty of Adab and Language students in August 2021 conducted a survey. It used a google form to find out the progress report in the measurement of religious moderation index. The instruments used to use four indicators proclaimed by the ministry of religion: the acceptance of Indonesian principles (Pancasila, Bhineka Tunggal Ika, NKRI, and the 1945 Constitution), anti-violence, and tolerance and acceptance of local wisdom. Then based on the results of the answer, formulated the index of religious moderation. The moderation index here is compiled by the IAIN Surakarta House of Religious Moderation as a primary reference for screening students at IAIN Surakarta. In addition, the assessment scale instrument is also used to measure the scale of understanding and satisfaction of activities that BIMA has organized as part of the process report.

The formula of the religious moderation index is presented as follows:
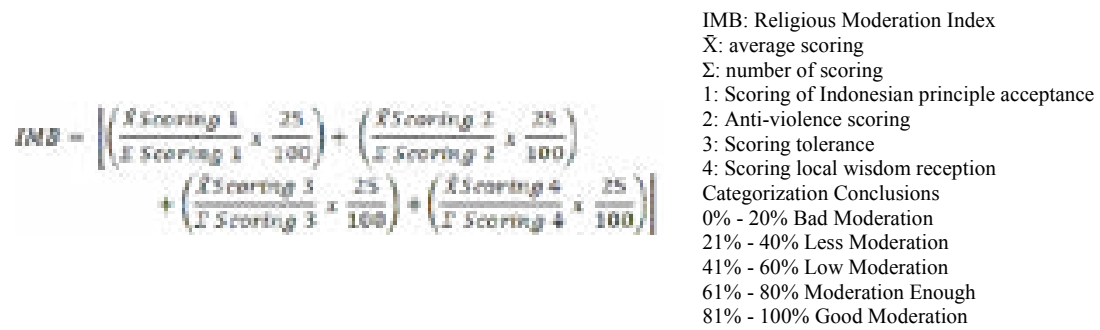

The Religious Moderation Index (IMB) is a quantitative indicator used to measure religious moderation. As presented by his ministry, Indicators of religious moderation are based on four criteria, namely National Commitment, Anti-Violence, Tolerance, and Cultural Acceptance. Each indicator consists of several questions and statements that describe themselves from the respondent. Scoring is done on a 5 -tier Likert scale. The sample was 238 respondents. The

${ }^{41}$ Edy Sutrisno, "Aktualisasi Moderasi Beragama Di Lembaga Pendidikan," Jurnal Bimas Islam, Volume 12, No. 2, (2019): 345, https://doi.org/10.37302/jbi. v12i2.113. 
results of the Religious Moderation Index report for respondents who have followed BIMA are as follows:

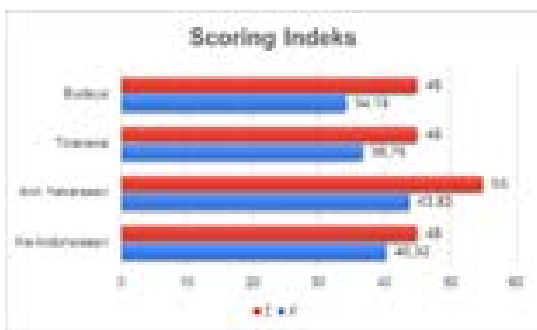

The student religious moderation index can be obtained based on BIMA assistance of $81.73 \%$ based on the above data. It means that following the index categorization shows that the religious moderation attitude of IAIN Surakarta students, especially samples from the Faculty of Adab and Language, is relatively good (moderate). When traced further through the percentage of scoring based on indicators, it was found that the Indonesian indicator had the highest percentage of $89.6 \%$. It proves that IAIN Surakarta students have a good acceptance of Indonesian principles that include Pancasila, Bhinneka Tunggal Ika, NKRI, and UUD 45, a pillar of the Indonesian nation.

In contrast, the percentage of scoring based on indicators shows the culture has the lowest value among others. The question/ statement item that appears here relates to the acceptance of cultural diversity and religious expression. Question items with low scoring in cultural indicators are related that dressing with Arabic style is more Islamic than traditional clothing, although equally close aurat. The second question item with the lowest scoring is that Islam today is not pure as the Prophet brought. It is because it has been mixed with culture, thus distorting the value of Islam itself. It means that cultural and religious acculturation in the Greater Solo area obscures the value of Islamic teachings. Although not explicit, as if there is an indication of leaning opinions in favor of puritanism movements. It is supported by the third lowest item related that Islam is one, not consisting of particular factions, such as madhhabs, Sunni-Shiites, and others. With this finding, students are still willing to accept the principle of Indonesia. Still, the existence of culture should not reduce the purity of Islamic teachings. Therefore, the evaluation that can be 
done is that differences in religious expression are fundamental to be given education by BIMA and "Rumah Moderasi Agama" (RMB). The following test measures whether there is a change in views or attitudes after participating in BIMA-organized activities. Based on the results of questionnaire answers conducted simple statistical data using paired-sample tests. Results are presented as follows:

Coaching Results Testing BIMA

Paired Samples Statistics

\begin{tabular}{llcrrr}
\hline & & \multicolumn{2}{c}{$\begin{array}{c}\text { Std. } \\
\text { Mean }\end{array}$} & \multicolumn{1}{c}{$\begin{array}{c}\text { Std. Error } \\
\text { Deviation }\end{array}$} \\
\hline Pair 1 & Before & 6.3333 & 238 & 1.92075 & .12477 \\
& Aftre & 7.7975 & 238 & 1.60016 & .10394 \\
& \multicolumn{4}{c}{ Paired Samples Correlations } & \\
& & &
\end{tabular}

\begin{tabular}{lrrrr}
\hline & & N & Correlation & \multicolumn{1}{c}{ Sig. } \\
\hline Pair 1 & Before \& After & 238 & .469 & .000
\end{tabular}

Based on the above results obtained, the religious moderation knowledge scale of 238 respondents before following BIMA was 6.3333 out of 10 , while participating in activities organized bima to 7.7975 out of 10 . Then with the analysis of the paired-sample test obtained a significance of $0.000<\alpha(0.05)$. So, it can be concluded that there are differences in views and attitudes after participating in bima-organized activities. The existence of religious moderation education activities proved to improve student moderation attitudes significantly.

The following result evaluates the implementation of religious moderation education by BIMA by looking at how necessary this education and scoring satisfaction were obtained during the activity. The results show that most respondents, namely students, need religious moderation education activities such as bima. Even the coverage was expanded in the Faculty of Adab and Language and throughout the other faculties. In addition, the student satisfaction rate was 7.83 out of 10. It means that the majority of students are satisfied with the results of education organized by BIMA. 


\section{CONCLUSION}

Based on the discussion, it can be drawn some conclusions. First, the actualization of religious moderation at IAIN Surakarta stems from intolerance and campus radicalism. It is through several institutional policies. They establish a House of Religious Moderation, Pancasila and National Studies Center, Center for The Study and Development of Pesantren Nusantara. In addition, religious moderation-based research is also developed for lecturers. Student activities such as $\mathrm{KKN}$, PBAK, and graduation began to insert religious moderation themes to stimulate the Islamic wasathiyah movement.

Second, the Faculty of Adab and Language pioneered the religious moderation movement by establishing a bima support unit useful for counter-radicalism in preventing measures against radicalism and intolerance. It is motivated by the activities of students covered in Islam. Still, it has become the land of the exclusive movement of Tarbiyah P3KMI. Thus, the emergence of BIMA units is the antithesis of the spread of student intolerance. It becomes the seeds of radicalism.

Third, to optimize prevention efforts by establishing moderation insight courses into one of the Faculty of Adab and Language mandatory courses that each study program must apply. Furthermore, there is also a monthly study on moderation and moderation assistance programs. It mainly targets the millennial generation, given the task of producing creative digital content in videos, posters, comics, and articles/articles essays based on religious moderation. Those who graduate will get a BIMA certificate which will be a requirement for the munaqosah trial. Based on the progress report of the bima program, it can be known that the development of the BIMA religious moderation program can increase the index of religious moderation. The majority of students need education related to religious moderation on campus.

\section{REFERENCES}

Adiwilaga, Rendy. "Puritanisme Dan Fundamentalisme Dalam Islam Transnasional Serta Implikasi Terhadap Pancasila Sebagai Ideologi Bangsa.” Journal of Governance, Volume 2, No. 1, (2017). 
Afrianty, Dina. "Islamic Education and Youth Extremism in Indonesia." Journal of Policing, Intelligence, and CounterTerrorism, Volume 7, No. 2, (2012): 134-46.

Aldy Aldya Putra, Faizal Irfandi. "Implementasi Quick Response (QR) Code Pada Aplikasi Pratinjau Konten Komik Cetak." Jurnal Siliwangi, Volume 4, No. 2, (2018): 104-11.

Andrea Lidwina. "94\% Orang Indonesia Akses YouTube Dalam Satu Bulan Terakhir.” Databoks, 2021.

Azra, Azyumardi. "Distinguishing Indonesian Islam: Some Lessons to Learn." Edited by Jajat Burhanudin and Kees van Dijk. Amsterdam: Amsterdam University Press, 2013.

Danandjaja, James. Folklor Indonesia: Ilmu Gosip, Dongeng, Dan Lain-Lain. Jakarta: PT. Pustaka Utama Grafiti, 1997.

Fahri, Mohamad, and Ahmad Zainuri. "Moderasi Beragama Di Indonesia.” Intizar, Volume 25, No. 2, (2019): 95-100.

Hefni, Wildani. "Moderasi Beragama Dalam Ruang Digital: Studi Pengarusutamaan Moderasi Beragama Di Perguruan Tinggi Keagamaan Islam Negeri." Jurnal Bimas Islam, Volume 13, No. 1, (2020): 1-22. https://doi.org/10.37302/jbi.v13i1.182.

Jazuli, Ahmad. "Strategi Pencegahan Radikalisme Dalam Rangka Pemberantasan Tindak Pidana Terorisme." Jurnal Ilmiah KEBIJAKAN HUKUM, Volume 2, No. 10, (2016).

Jura, Demsy. "Religious Moderation: An Approach Of Religious Life In Indonesia." Jurnal Inovasi Penelitian, Volume 1, No. 10, (2021).

Kementerian Agama RI. Rencana Strategis Kementerian Agama Tahun 2020-2024, 2020.

LP2M IAIN Surakarta. "Pengumuman Pembagian Kelompok Dan Dosen Pembimbing Lapangan (DPL) KKN Kerso Darma 2021." LP2M, 2021. https://lp2m.iain-surakarta.ac.id/2021/06/13/ pengumuman-pembagian-kelompok-dan-dosen-pembimbinglapang-dpl-kkn-kersodarma-2021/. 
Nurkhoiron, Muhammad. "Liberalisasi Sebagai Moderasi Islam Dalam Masyarakat Paska Sekuler." MIMIKRI, Volume 6, No. 1, (2020): 1-16.

PPIM UIN Jakarta. "Ringkasan Eksekutif Hasil Penelitian Potret Moderasi Beragama Di Kalangan Mahasiswa Muslim Kasus Tiga Kampus Islam (Jakarta, Bandung, Yogyakarta),” 2021, $1-13$.

Pusat Pengkajian Islam \& Masyarakat UIN Jakarta. "Riset Sikap Dan Perilaku Terhadap Keberagaman, Berbangsa dan Bernegara Pada Civitas Akademika PTKIN." SURVEI PPIM UIN JAKARTA, 2021.

Putri, Arindya Iryana. "SEMINAR BIMA (BILIK ISLAM MODERASI DAN ADAB) MAKNA \& PENGUATAN NILAINILAI MODERASI ISLAM DI ERA DIGITAL." Fakultas Adab dan Bahasa IAIN Surakarta, 2020. https://fab.iainsurakarta.ac.id/seminar-bima-bilik-islam-moderasi-dan-adabmakna-penguatan-nilai-nilai-moderasi-islam-di-era-digital/.

Sugiyono. Metode Penelitian Bisnis: Pendekatan Kuantitatif, Kualitatif, Kombinasi, $R \& D$. Edited by Sofia Yustiyani Suryandari. 3rd ed. Bandung: CV Alfabeta, 2017.

Suharto, Toto. Moderasi Bergama Berbasis Kurikulum Islam Rahmatan Lil-'Alamin. Jakarta: Puslitbang Pendidikan Agama dan Keagamaan Badan Litbang dan Diklat Kemenag, 2020.

_. "Remoderasi Pendidikan Islam Di Indonesia: Tantangan Ideologis.” IAIN Surakarta, no. February (2020): 1-62.

Suharto, Toto, and Ja'far Assagaf. "Membendung Arus Paham Keagamaan Radikal Di Kalangan Mahasiswa PTKIN.” AlTahrir: Jurnal Pemikiran Islam, Volume 14, No. 1, (2014): 157. https://doi.org/10.21154/al-tahrir.v14i1.72.

Sutrisno, Edy. "Aktualisasi Moderasi Beragama Di Lembaga Pendidikan.” Jurnal Bimas Islam, Volume 12, No. 2, (2019): 323-48. https://doi.org/10.37302/jbi.v12i2.113.

Syukri, Fathudin AW, and Sudiyatno. "Peningkatan Perilaku Religius Mahasiswa Melalui Integrasi Pembelajaran Pendidikan Agama 
Islam (PAI) Dan Pembinaan Di Unit Kegiatan Keagamaan Mahasiswa." Seminar Hasil Penelitian Lemlit UNY, 2008.

Tim BIMA. "BIMA (Bilik Moderasi Islam dan Adab)." Fakultas Adab dan Bahasa IAIN Surakarta, 2020. https://fab.iainsurakarta.ac.id/unit-penunjang/unit-p3kmi/.

Tim P3KMI Fakultas Tarbiyah dan Bahasa IAIN Surakarta. Muslim Integral: Buku Program Pendampingan Pengembangan Kepribadian Muslim Integral (P3KMI). Cet.I. Yogyakarta: Cipta Media Aksara, 2012.

Tim Penyusun Kementerian Agama. Moderasi Beragama. Jakarta: Badan Litbang dan Diklat Kementerian Agama RI, 2019.

Widodo, M. Hafidh. "Ideologi Takfiri Muhammad Al-Maqdisi : Memahami Hubungan Beragama Dan Bernegara Perspektif Maqāshid Asy-Syarı̄'Ah.” Living Islam, Volume 1, No. 2, (2018).

Zuhdi, Muhammad Harfin. "Radikalisme Agama dan Upaya Deradikalisasi Pemahaman Keagamaan." AKADEMIKA, Volume 22, No. 1, (2017): 92-105. 